\title{
Glutamate-mediated inhibition of oxidative phosphorylation in cultured retinal cells
}

\author{
Ana Cristina Rego ${ }^{\mathrm{a}, \mathrm{b}}$, Maria Sancha Santos ${ }^{\mathrm{a}}$, Catarina Resende Oliveira ${ }^{\mathrm{a}, \mathrm{b}, *}$ \\ ${ }^{a}$ Center for Neurosciences of Coimbra, University of Coimbra, Coimbra, Portugal \\ ${ }^{\mathrm{b}}$ Faculty of Medicine, University of Coimbra, 3000 Coimbra Codex, Portugal
}

Received 22 March 1999; accepted 22 July 1999

\begin{abstract}
Glutamate is an excitotoxin responsible for causing neuronal damage associated with mitochondria dysfunction. We have analyzed the relationship between the mitochondrial respiratory rate, the membrane potential $(\Delta \Psi)$ and the activity of mitochondrial complexes in retinal cells in culture, used as neuronal models. Glutamate $(10 \mu \mathrm{M}-10 \mathrm{mM})$ dose-dependently decreased the $\mathrm{O}_{2}$ consumption and the membrane potential. A linear correlation was found between these parameters, suggesting that the mitochondrial respiratory function was affected. Exposure to glutamate $(100 \mu \mathrm{M})$ for $10 \mathrm{~min}$, in the absence of $\mathrm{Mg}^{2+}$, inhibited the activity of complex I $(26.3 \%)$, complexes II/III $(22.2 \%)$ and complex IV (26.7\%). MK-801 ((+)-5-methyl-10,11dihydro-5H-dibenzo[a,d]-cyclohepten-5,10-imine hydrogen maleate), a non-competitive antagonist of the NMDA ( $N$-methyl-Daspartate) receptors, completely reversed the effect exerted by $100 \mu \mathrm{M}$ glutamate at the level of complexes I, II/III and IV. These results suggest that NMDA receptor-mediated inhibition of mitochondrial respiratory chain complexes may be responsible for the alteration in the respiratory rate of chick retinal cells submitted to glutamate. (C) 2000 Elsevier Science Ltd. All rights reserved.
\end{abstract}

Keywords: Glutamate; Mitochondria; NMDA receptor; Retinal cells

\section{Introduction}

Glutamate has a fundamental role in normal brain function, in the physiological processes of learning and memory, and also in many pathological processes,

Abbreviations: AMPA, $\alpha$-amino-3-hydroxy-5-methyl-4-isoxazolepropionic acid; BME, basal medium of Eagle; CNQX, 6-cyano-7nitroquinoxaline-2; 3-dione; HO; hydroxyl radical; MK-801, $(+)$ -5-methyl-10; 11-dihydro-5H-dibenzo[a,d]-cyclohepten-5; 10-imine hydrogen maleate; Mn-SOD, manganese superoxide dismutase; MTT, 3-(4; 5-dimethylthiazol-2-yl)-2,5-diphenyltetrazolium bromide; NMDA, $N$-methyl-D-aspartate; NO, nitric oxide; NOS, nitric oxide synthase; $\mathrm{O}_{2}^{--}$, superoxide radical; PMS, phenazine methosulfate; $\mathrm{ONOO}^{-}$, peroxynitrite; ROS, reactive oxygen species; TMPD, $N$; $N, N^{\prime} ; \quad N^{\prime}$-tetramethyl-p-phenylenediamine; $\mathrm{TPP}^{+}$, tetraphenylphosphonium ${ }^{+}$.

* Corresponding author. Tel.: +351-39-820190; fax: +351-39822776 .

E-mail address: croliveira@gemini.ci.uc.pt (C.R. Oliveira). such as trauma or ischemia, and in a number of neurodegenerative disorders, such as Alzheimer's disease, Amyotrophic lateral sclerosis, Parkinson's disease and Huntington's disease. Excitotoxic neuronal injury depends on the interaction of glutamate with the receptors located principally on postsynaptic neurons. The ionotropic glutamate receptors comprise the NMDA and the non-NMDA receptors, which include the $\alpha$-amino-3-hydroxy-5-methyl-4-isoxazole-propionic acid (AMPA) and the kainate receptors subtype (Vizi et al., 1997; Tapia et al., 1999). Upon activation, these receptors are responsible for the deregulation of the ionic fluxes across the cell membrane, leading to increases in intracellular $\left[\mathrm{Ca}^{2+}\right]$ and $\left[\mathrm{Na}^{+}\right]$. Generation of reactive oxygen species (ROS), namely nitric oxide (NO) (Gunasekar et al., 1995) and superoxide radicals $\left(\mathrm{O}_{2}^{-}\right)$(Lafon-Cazal et al., 1993) have been shown to require the activation of the NMDA receptors and are suggested to be highly involved in 
the progression of neurodegeneration. NO can easily react with the $\mathrm{O}_{2}^{--}$generated by the mitochondria and produce $\mathrm{ONOO}^{-}$(peroxynitrite), mediating the formation of the hydroxyl radical (HO), one of the most deleterious radicals in living systems.

At the level of the mitochondria respiratory chain, $\mathrm{O}_{2}^{--}$is formed by complexes I and III under normal conditions (Turrens, 1997). After exposure to glutamate, mitochondria has been shown to play an important role in buffering cytoplasmic $\mathrm{Ca}^{2+}$ (Budd and Nicholls, 1996; Wang and Thayer, 1996) and production of ROS was observed (Dugan et al., 1995; Bindokas et al., 1996; Castilho et al., 1999). Furthermore, glutamate was shown to affect the mitochondrial membrane potential (Ankarcrona et al., 1995) and to reduce the energy production (Budd and Nicholls, 1996; Ankarcrona et al., 1995). Previous studies reported an impaired oxygen consumption after exposure to glutamate (Atlante et al., 1996; Almeida et al., 1998), suggesting that an impairment in energy metabolism is involved in excitotoxicity.

In this work, experimental studies were performed to establish whether glutamate was responsible for a reduction of mitochondrial function in cultured retinal cells. These cells have been shown to be good models for neuropathological conditions associated with excitotoxicity, particularly because the retina is a CNS structure, glutamate is used as a major excitatory input and, similarly to other neuronal cell types, the retinal cells are energy-dependent and are very sensitive to oxidative damage. We found that low glutamate concentrations highly decreased mitochondrial respiration and the membrane potential, which seems to occur as a consequence of a reduction in the activity of the respiratory chain complexes (I, II/III and IV), in a process mediated by the activation of the NMDA receptors.

\section{Experimental procedures}

\subsection{Materials}

Basal medium of Eagle (Earle's salts-BME) was purchased from Sigma (USA), trypsin from GIBCO (UK) and fetal calf serum from BioChrom KG (Berlin, Germany). MK-801 ((+)-5-methyl-10,11-dihydro-5Hdibenzo[a,d]-cyclohepten-5,10-imine hydrogen maleate) was a kind gift of Merck Sharp and Dohme (West Point, PA, USA). Ubiquinone-1 was a kind gift from Eisai Co., Tokyo, Japan. All other chemicals were of the purest grade available from regular commercial sources.

\subsection{Retinal cell cultures}

Primary cultures of retinal cells were prepared from 8-day-old chick embryos as described previously (Rego et al., 1996). The cells were plated at a density of $2.09 \times 10^{6}$ cells $/ \mathrm{cm}^{2}$ for the measurement of oxygen consumption and membrane potential, or at a density of $0.44 \times 10^{6} \mathrm{cell} / \mathrm{cm}^{2}$ for determining the activities of mitochondrial complexes. The cells were plated on poly-L-lysine $(0.1 \mathrm{mg} / \mathrm{ml})$ coated $100 \mathrm{~mm}$ Petri dishes, avoiding the growing of a large proportion of Müller cells. For $\left[\mathrm{Ca}^{2+}\right]_{i}$ fluorescence determinations, the retinal cells were plated at a density of $0.64 \times 10^{6} \mathrm{cell} / \mathrm{cm}^{2}$ on poly-L-lysine coated $10 \mathrm{~mm}$ glass coverslips. The cells were cultured for 5 to 6 days in BME medium buffered with $25 \mathrm{mM}$ Hepes and $10 \mathrm{mM} \mathrm{NaHCO}$, and supplemented with $5 \%$ fetal calf serum (heat inactivated), penicillin (100 units $/ \mathrm{ml})$ and streptomycin $(100 \mu \mathrm{g} / \mathrm{ml})$, and maintained at $37^{\circ} \mathrm{C}$ in an atmosphere of $95 \%$ air and $5 \% \mathrm{CO}_{2}$. Similar retinal cultures were described to be highly enriched in amacrine neuronlike cells, but also containing neurons resembling bipolar cells, and some few glial cells (Huba and Hofmann, 1990).

Before the experiments, the culture medium was removed and the retinal cells were washed twice with $\mathrm{Na}^{+}$saline solution, containing (in $\mathrm{mM}$ ): $\mathrm{NaCl}$ 140.0, $\mathrm{KCl} 5.0, \mathrm{CaCl}_{2}$ 1.5, $\mathrm{MgCl}_{2}$ 1.0, $\mathrm{NaH}_{2} \mathrm{PO}_{4} 1.0$, glucose 5.6 and Hepes 20.0, at $\mathrm{pH} 7.4\left(37^{\circ} \mathrm{C}\right)$, and pre-equilibrated in this solution for $10-15 \mathrm{~min}$, at $37^{\circ} \mathrm{C}$, in a waterbath. For the $\left[\mathrm{Ca}^{2+}\right]_{i}$ measurements, the cells were incubated with $100 \mu \mathrm{M}$ glutamate in $\mathrm{Na}^{+}$solution, at $\mathrm{pH} 7.4\left(37^{\circ} \mathrm{C}\right)$. For the measurement of the activity of mitochondrial complexes, the cells were incubated for $10 \mathrm{~min}$ in the absence (control) or in the presence of glutamate $(100 \mu \mathrm{M})$, in $\mathrm{Na}^{+}$medium without $\mathrm{Mg}^{2+}$. When present, MK-801 $(5 \mu \mathrm{M})$ was incubated 5-10 $\mathrm{min}$ prior and during the glutamate exposure, in the absence of $\mathrm{Mg}^{2+}$ to ensure maximal opening of the NMDA receptor-associated channel. For the measurement of $\mathrm{O}_{2}$ consumption or the membrane potential, the retinal cells were dissociated with $0.01 \%$ trypsin in $\mathrm{Na}^{+}$saline solution, for $15 \mathrm{~min}$, at $37^{\circ} \mathrm{C}$. The cells were recovered and centrifuged twice to remove the medium containing the trypsin, and further resuspended in $\mathrm{Na}^{+}$solution.

\subsection{Measurement of oxygen consumption}

The consumption of oxygen was measured polarographically by using an oxygen electrode (Hansatech type), in $\mathrm{Na}^{+}$saline solution containing $5.6 \mathrm{mM}$ glucose $(0.4 \mathrm{ml}$, final volume), before (control) and after glutamate $(10 \mu \mathrm{M}-10 \quad \mathrm{mM})$ addition, at $37^{\circ} \mathrm{C}$. Continuous stirring allowed $\mathrm{O}_{2}$ to diffuse freely, although not causing damage to the cell suspension. 
Respiration rates were calculated assuming an oxygen concentration of $454 \mathrm{nAt} \mathrm{O} / \mathrm{ml}$ in the experimental medium at $37^{\circ} \mathrm{C}$. Incubation with $1 \mathrm{mM} \mathrm{KCN}$ totally inhibited the respiration rate. The rate of oxygen uptake, obtained as a tangent at the initial part of the progress curve, was calculated as nanoatoms $\mathrm{O} / \mathrm{min} /$ $\mathrm{mg}$ protein, and expressed as a percentage of control.

\subsection{Measurement of membrane potential ( $\Delta \Psi)$}

The membrane potential was estimated by calculating transmembrane distribution of $\mathrm{TPP}^{+}$(tetraphenylphosphonium) with a $\mathrm{TPP}^{+}$selective electrode. $\mathrm{TPP}^{+}$ $(4 \mu \mathrm{M})$ uptake was followed by a decrease of $\mathrm{TPP}^{+}$ concentration in $\mathrm{Na}^{+}$saline solution $(0.8 \mathrm{ml}$, final volume), at $37^{\circ} \mathrm{C}$, after incubation of the retinal cells (about $0.25 \mathrm{mg}$ protein) with $10 \mu \mathrm{M}-10 \mathrm{mM}$ glutamate, under magnetic stirring. The mitochondrial $\Delta \Psi$ was determined as relative changes in potential rather than absolute values, and estimated from the following equation (Kamo et al., 1979):

$\Delta \Psi(m V)=59 \log (v / V)-59 \log \left(10^{\Delta E / 59}-1\right)$,

where $v, V$ and $\Delta E$ are the mitochondrial volume, the volume of incubation medium and the deflection of electrode potential from the baseline, respectively. This equation was derived assuming that $\mathrm{TPP}^{+}$distribution between the mitochondria and the medium follows the Nernst equation and that the law of mass conservation is applicable. The results were expressed as a percentage of control, in the absence of glutamate.

\subsection{Measurement of mitochondrial complexes activity}

After incubation, the retinal cells were collected by gentle scraping in $0.25 \mathrm{M}$ sucrose $/ 5 \mathrm{mM}$ Hepes, $\mathrm{pH} 7.4$ $\left(0-4{ }^{\circ} \mathrm{C}\right)$, to obtain a cell suspension. The suspension of retinal cells was rapidly frozen and kept at $-80^{\circ} \mathrm{C}$. Just before the measurements, the cellular suspension was homogenised. Measurement of complexes activity was performed in sucrose medium, containing (in $\mathrm{mM}$ ): sucrose $130, \mathrm{KCl} 50, \mathrm{MgCl}_{2} 5, \mathrm{KH}_{2} \mathrm{PO}_{4} 5$ and Hepes 5, at $\mathrm{pH} 7.4\left(30^{\circ} \mathrm{C}\right)$. The enzymatic activities were assayed at $30^{\circ} \mathrm{C}$.

\subsubsection{Complex I (NADH-ubiquinone oxidoreductase)}

The decrease in absorbance of NADH at $340 \mathrm{~nm}$ was measured by following the method described by Ragan et al. (1987), in a medium supplemented with $1 \mathrm{mM} \mathrm{KCN}, 150 \mu \mathrm{M} \mathrm{NADH}, 1.25 \mathrm{mg} / \mathrm{mg}$ free fatty acid BSA and retina homogenates (corresponding to about $50 \mu \mathrm{g}$ protein) in $1 \mathrm{ml}$ final volume. After a preincubation for $5 \mathrm{~min}$, at $30^{\circ} \mathrm{C}$, the reaction was initiated with $50 \mu \mathrm{M}$ ubiquinone-1. Following $5 \mathrm{~min}$ $\left(30^{\circ} \mathrm{C}\right), 10 \mu \mathrm{M}$ rotenone was added to define the change in absorbance due to complex I activity. Rotenone inhibited complex I by about $90 \%$. NADH oxidation upon addition of ubiquinone-1 was linear up to $15 \mathrm{~min}$. The results were calculated as $\mathrm{nmol} / \mathrm{min} / \mathrm{mg}$ protein and expressed as a percentage of control, in the absence of glutamate.

\subsubsection{Complex II/III (succinate dehydrogenase plus succinate-cytochrome-c-reductase)}

The activity of complex II/III was measured in sucrose medium supplemented with $8 \mu \mathrm{M}$ rotenone, $1 \mathrm{mM} \mathrm{KCN}, 54 \mu \mathrm{M}$ oxidized cytochrome c and retina homogenates, in a modified method as described by King (1967). After pre-incubation for $5 \min \left(30^{\circ} \mathrm{C}\right)$, the reaction was initiated by the addition of $5 \mathrm{mM}$ succinate. Appearance of reduced cytochrome $\mathrm{c}$ was measured spectrophotometrically at $550 \mathrm{~nm} .0 .1 \mu \mathrm{g}$ antimycin A completely inhibited enzyme activity. The results were calculated as $\mathrm{nmol} / \mathrm{min} / \mathrm{mg}$ protein and expressed as a percentage of control, in the absence of glutamate.

\subsubsection{Complex IV (cytochrome oxidase)}

The activity of complex IV was measured polarographically, by following the method described previously (Brautigan et al., 1978). The retina homogenates were resuspended in sucrose medium, supplemented with $2 \mu \mathrm{M}$ rotenone, $0.25 \mu \mathrm{g} / \mathrm{ml}$ antimycin $\mathrm{A}, 10 \mu \mathrm{M}$ cytochrome c, $0.75 \mathrm{mg} / \mathrm{ml}$ Triton X-100. The measurement of complex IV was initiated upon the addition of $5 \mathrm{mM}$ ascorbate plus $0.25 \mathrm{mM}$ TMPD $\left(N, N, N^{\prime}, N^{\prime}\right.$-tetramethyl-p-phenylenediamine). Incubation with $1 \mathrm{mM}$ $\mathrm{KCN}$ inhibited complex IV activity. The results were calculated as nanoatoms $\mathrm{O} / \mathrm{min} / \mathrm{mg}$ protein and expressed as a percentage of control, in the absence of glutamate.

\section{6. $\left[\mathrm{Ca}^{2+}\right]_{i}$ measurements}

The $\left[\mathrm{Ca}^{2+}\right]_{i}$ in cultured retinal cells was measured by using the probe indo-1/AM $(3 \mu \mathrm{M})$, as described previously (Rego et al., 1996), except that after loading, fluorescence was measured in control (non-treated) retinal cells, and $100 \mu \mathrm{M}$ glutamate was added to the cuvette.

\subsection{Statistical procedures}

All data are expressed as the means \pm SEM of the indicated number of independent experiments, run in duplicate or triplicate. Statistical comparisons were performed by the unpaired two-tailed Student's $t$-test for the comparison of the means of two Gaussian populations or by the one-way ANOVA Tukey posttest for multiple comparisons. 


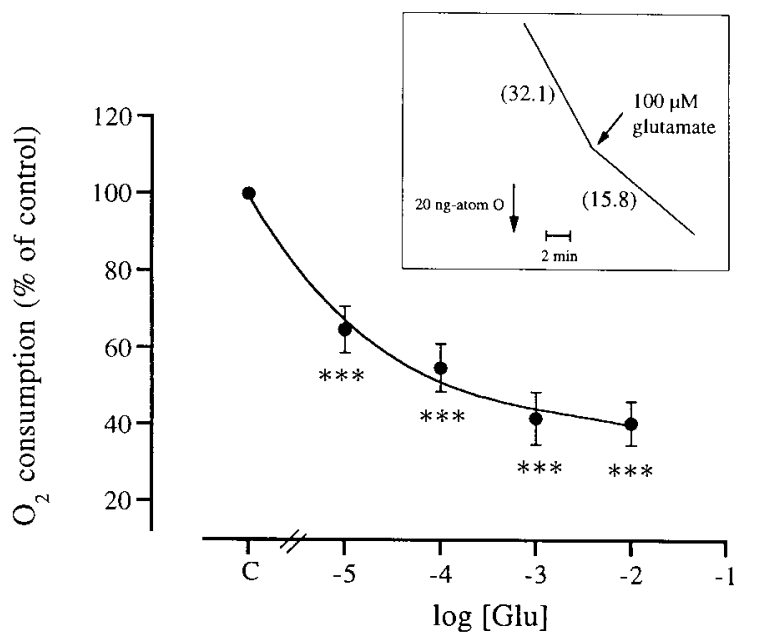

Fig. 1. Effect of glutamate on the consumption of $\mathrm{O}_{2}$ in dissociated retinal cells. The $\mathrm{O}_{2}$ consumption was measured polarographically before (control, C) and after glutamate $(10 \mu \mathrm{M}-10 \mathrm{mM}$ Glu) addition, in $\mathrm{Na}^{+}$saline solution containing $5.6 \mathrm{mM}$ glucose. The rate of oxygen uptake was expressed as a percentage of control, in the absence of glutamate. Insert shows the polarographic trace of a representative experiment before and after addition of $100 \mu \mathrm{M}$ glutamate; the numbers in brackets represent rates of respiration in ng.atom $\mathrm{O} / \mathrm{mg}$ protein $/ \mathrm{min}$. Data are the means \pm SEM of seven to ten measurements, by using four to five suspensions of retinal cells, obtained from independent preparations. Statistical significance: ${ }^{* * *} P<0.001$ as compared to the control.

\section{Results}

\subsection{Glutamate inhibits the rate of mitochondrial respiration in cultured retinal cells}

Initial experiments were performed to measure the rate of $\mathrm{O}_{2}$ consumption in the retinal cells. In control retinal cells, not submitted to glutamate exposure, cellular respiration was of $32.07 \pm 2.07$ nanoatoms $/ \mathrm{min} /$ $\mathrm{mg}$ protein. Mitochondrial respiration was shown to be responsible for the observed effects, because cyanide, an inhibitor of mitochondrial cytochrome oxidase activity, completely inhibited $\mathrm{O}_{2}$ consumption (not shown).

Addition of L-glutamate $(10 \mu \mathrm{M}-10 \mathrm{mM})$ induced a dose-dependent inhibition of $\mathrm{O}_{2}$ consumption in retinal cells (Fig. 1). The inhibition of $\mathrm{O}_{2}$ consumption occurred right upon exposure to glutamate (Fig. 1, insert). Major decreases in mitochondrial respiration were observed in the presence of low glutamate concentrations (Fig. 1), because the $\mathrm{O}_{2}$ consumption decreased in the presence of 10 or $100 \mu \mathrm{M}$ glutamate, respectively, to $64.87 \pm 6.06$ or $54.94 \pm 6.27 \%$ of control, in the absence of glutamate $(P<0.001)$. In the presence of $10 \mathrm{mM}$ glutamate $\mathrm{O}_{2}$ consumption was reduced to $40.60 \pm 5.79 \%$ (Fig. 1). The stereoisomer Dglutamate, used at the same concentrations, did not

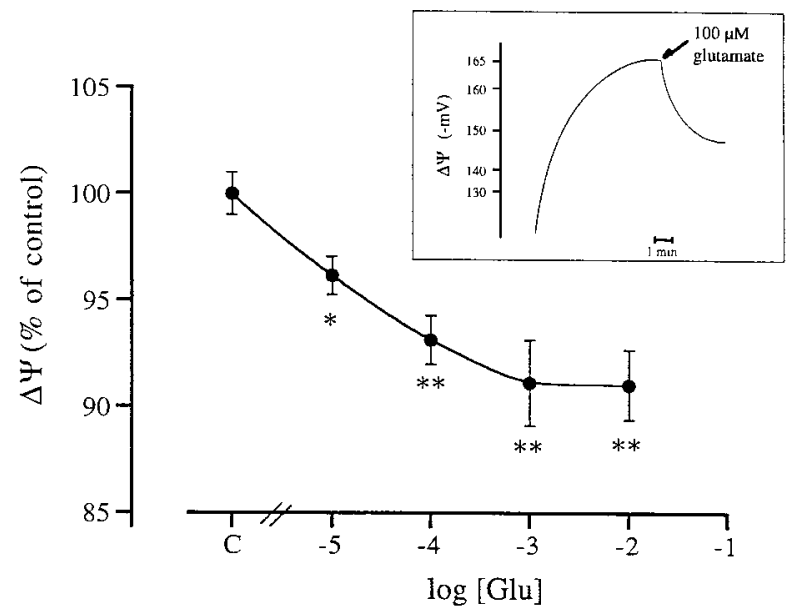

Fig. 2. Effect of glutamate on the membrane potential $(\Delta \Psi)$ of retinal cells. The membrane potential $(\Delta \Psi)$ was monitored by following the accumulation of $\mathrm{TPP}^{+}$by retinal cells submitted to glutamate $(10 \mu \mathrm{M}-10 \mathrm{mM})$, by using a $\mathrm{TPP}^{+}$selective electrode. Insert shows the $\Delta \Psi$ after addition of $100 \mu \mathrm{M}$ glutamate, estimated according to Kamo et al. (1979). Data, expressed as a percentage of control (C), in the absence of glutamate, are the means \pm SEM from six to seven determinations, by using three independent retinal cell suspensions. Statistical significance: ${ }^{*} P<0.05$ or ${ }^{* *} P<0.01$ as compared to the control.

elicite the reduction in the consumption of $\mathrm{O}_{2}$ (not shown).

\subsection{Glutamate decreases the membrane potential $(\Delta \Psi)$}

Exposure to glutamate $(10 \mu \mathrm{M}-10 \mu \mathrm{mM})$, induced a dose-dependent decrease in $\Delta \Psi$ (Fig. 2). Similarly as determined by the measurement of $\mathrm{O}_{2}$ consumption, major decreases in $\Delta \Psi$ were observed in the presence of low concentrations of glutamate $(10$ or $100 \mu \mathrm{M})$, with values that decreased from $\Delta \Psi=-166.35 \pm 1.67 \mathrm{mV}$ in controls, to $\Delta \Psi=$ $-159.97 \pm 1.50 \mathrm{mV} \quad(P<0.05) \quad$ or $\quad \Delta \Psi=-154.95 \pm$ $1.92 \mathrm{mV}(P<0.01)$, in the presence of 10 or $100 \mu \mathrm{M}$ glutamate, respectively. The $\Delta \Psi$ was not significantly affected upon addition of a high concentration of glutamate $(10 \mathrm{mM})$ as compared to $1 \mathrm{mM}$ glutamate (Fig. 2). Addition of a depolarizing concentration of $\mathrm{KCl}(50 \mathrm{mM})$, before glutamate exposure, did not affect significantly the values of $\Delta \Psi$ (not shown), suggesting that changes in $\Delta \Psi$ occurring after glutamate addition were mostly a function of changes in mitochondrial membrane potential. These data also suggested that the trypsinization may have affected the plasma membrane potential of cultured retinal cells. In order to correlate changes in the respiratory rate with alterations in membrane potential, these two parameters were plotted in Fig. 3. We observed a linear correlation ( $r$ value of 0.97 ) between the respiratory rate and the $\Delta \Psi$ in retinal cells exposed to increasing 


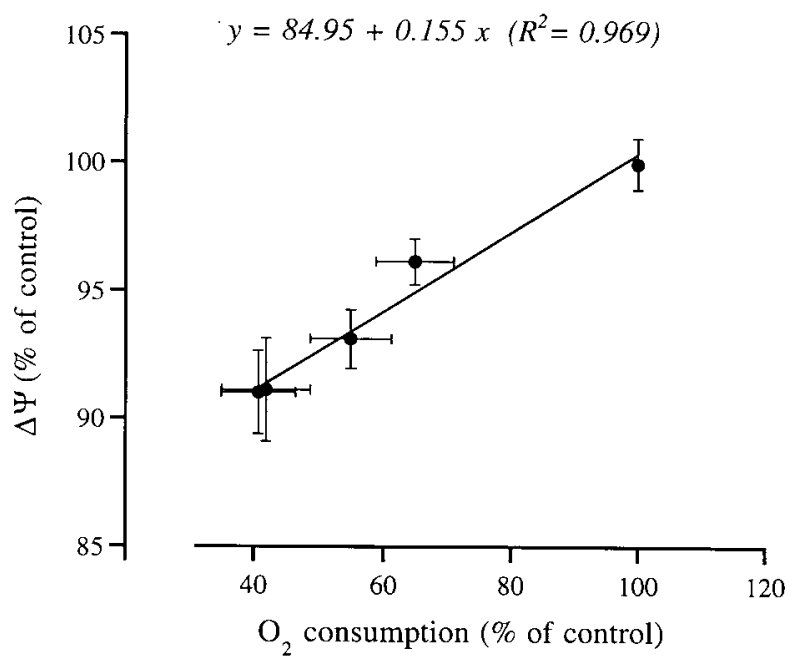

Fig. 3. Correlation between $\mathrm{O}_{2}$ consumption and the membrane potential $(\Delta \Psi)$. Data are the means \pm SEM, as plotted in Figs. 1 and 2.

glutamate concentrations (Fig. 3), suggesting that changes in membrane potential may reflect changes at the level of the mitochondrial membrane.

\subsection{NMDA receptors mediate the reduction in the activity of mitochondrial complexes after glutamate exposure}

Because changes in the consumption of $\mathrm{O}_{2}$ upon exposure to glutamate may result from the dysfunction of mitochondrial complexes, affecting the redox component(s) of the mitochondrial respiratory chain, we measured the activities of complex I (NADH-ubiquinone oxidoreductase), complex II/III (succinate dehydrogenase plus succinate-cytochrome-c-reductase) and complex IV (cytochrome oxidase) in homogenates obtained from retinal cells exposed to $100 \mu \mathrm{M}$ glutamate (Fig. 4). The effect of MK-801, a non-competitive antagonist of the NMDA subtype of glutamate receptors, was also analyzed.

Exposure to glutamate in $\mathrm{Mg}^{2+}$-free medium reduced significantly the activities of complex I $(26.3 \%$ inhibition, $P<0.01)$, complex II/III $(22.2 \%$ inhibition, $P<0.05)$ and complex IV $(26.7 \%$ inhibition, $P<0.01)$. The reduction in the activity of mitochondrial complexes (I, II/III or IV) was completely reversed when the cells were incubated with glutamate $(100 \mu \mathrm{M})$ in the presence of MK-801 $(5 \mu \mathrm{M})$, as observed in Fig. 4, indicating that the inhibitory effects were mediated through the activation of the NMDA receptors. When measuring the activity of complex II/ III, glutamate plus MK-801 enhanced the activity observed in the control.

Data from Fig. 4 indicated that the inhibition of the mitochondrial respiratory chain by glutamate was due to the activation of the NMDA receptors in retinal
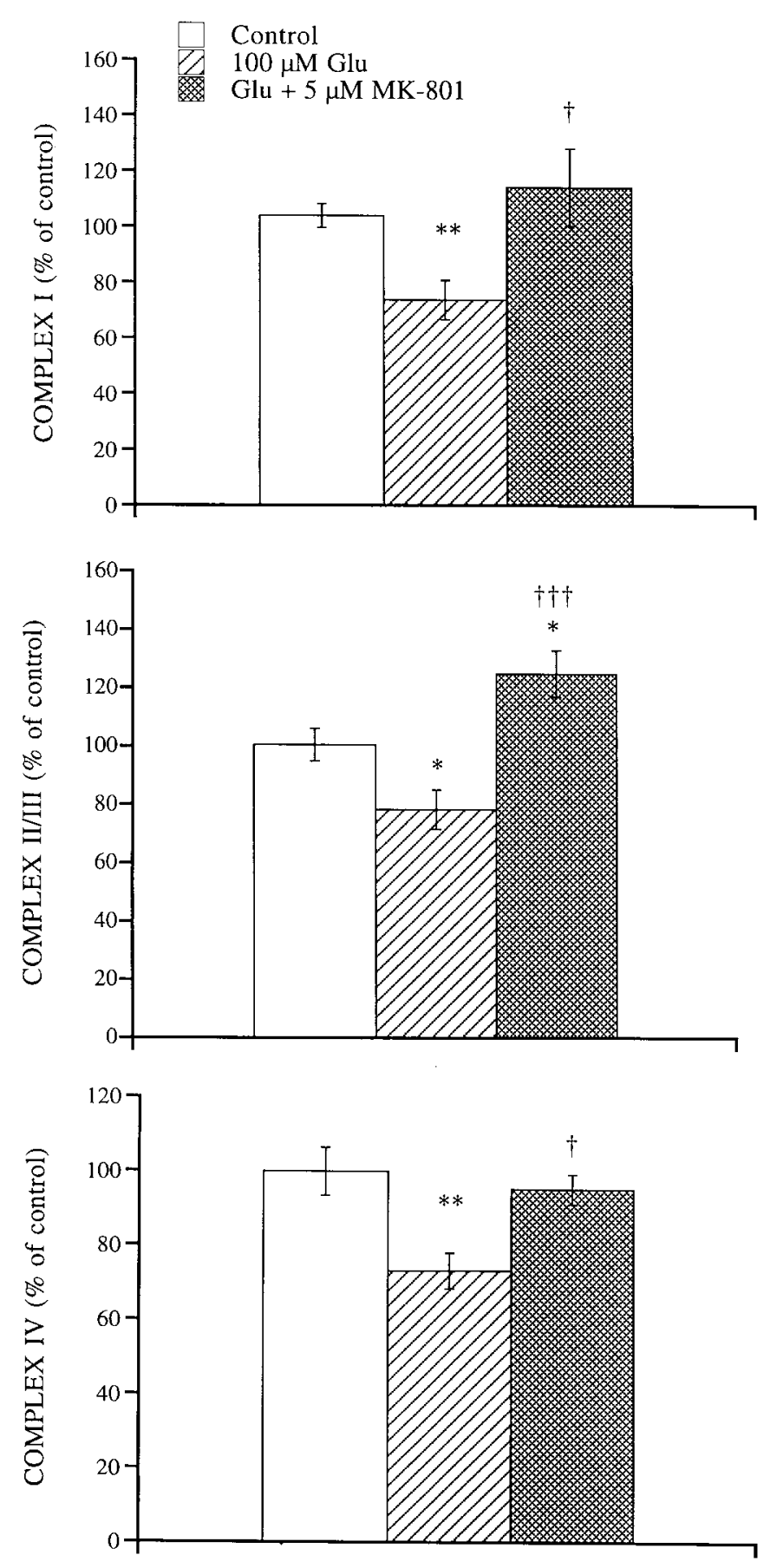

Fig. 4. Effect of glutamate on the activities of mitochondrial respiratory complexes (I, II/III and IV). Retinal cells were incubated with $100 \mu \mathrm{M}$ glutamate $(\mathrm{Glu})$, for $10 \mathrm{~min}$, at $37^{\circ} \mathrm{C}$. Some cells submitted to glutamate were also exposed to $5 \mu \mathrm{M}$ MK- 801 in $\mathrm{Mg}^{2+}$-free medium (Glu $+5 \mu \mathrm{M}$ MK-801). The activities of mitochondrial complexes I (NADH-ubiquinone oxidoreductase), II/III (succinate dehydrogenase plus succinate-cytochrome-c-reductase) and IV (cytochrome oxidase) were measured in sucrose medium, at $30^{\circ} \mathrm{C}$. Data are the means \pm SEM from the number of experiments indicated in the figure. Statistical significance: ${ }^{*} P<0.05$ or ${ }^{* *} P<0.01$ as compared to control, in the absence of glutamate; $P<0.05$ or $P<0.001$ in comparison with cells exposed to $100 \mu \mathrm{M}$ Glu. 


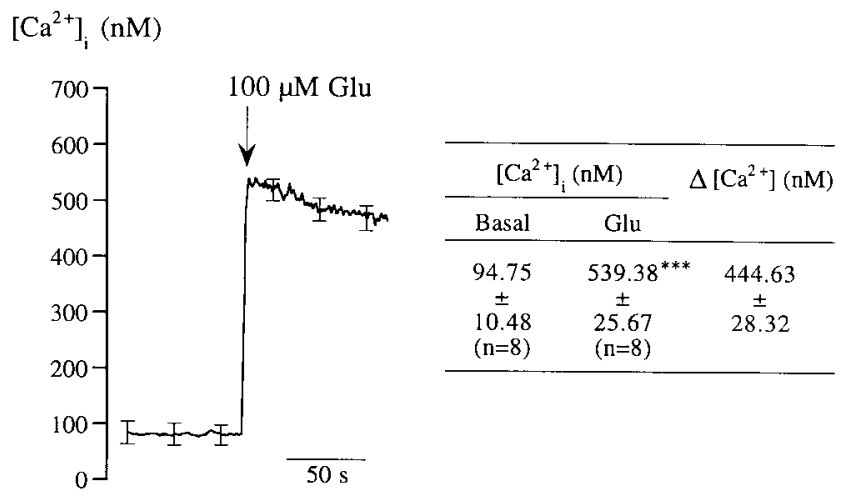

Fig. 5. Intracellular $\mathrm{Ca}^{2+}$ concentration $\left(\left[\mathrm{Ca}^{2+}\right]_{i}\right)$ after glutamate exposure. $\left[\mathrm{Ca}^{2+}\right]_{i}$ was measured by using the fluorescent probe indo-1/ AM, as described previously (Rego et al, 1996). The retinal cells were exposed to $100 \mu \mathrm{M}$ glutamate. Data represent the means \pm SEM from eight independent experiments. $\Delta\left[\mathrm{Ca}^{2+}\right]_{i}$ of $444.63 \pm 28.32 \mathrm{nM}$ was determined by calculating the difference between data obtained after glutamate exposure and the basal, before glutamate exposure.

cells in culture. Because many of the effects mediated by this receptor are due to increases in $\left[\mathrm{Ca}^{2+}\right]_{i}$ we also measured whether glutamate increased intracellular $\mathrm{Ca}^{2+}$, by using the fluorescent probe indo-1. Fig. 5 shows the increase in $\left[\mathrm{Ca}^{2+}\right]_{i}$ from $94.75 \pm 10.48 \mathrm{nM}$, under non-stimulated conditions (basal), to $539.38 \pm 25.67 \mathrm{nM}$ after addition of $100 \mu \mathrm{M}$ glutamate.

\section{Discussion}

In this study, we give evidence that glutamate reduces the mitochondrial respiratory rate due to the inhibition of complex I (NADH-ubiquinone oxidoreductase), complexes II/III (succinate dehydrogenase plus succinate-cytochrome-c-reductase) and complex IV (cytochrome oxidase) by about $20 \%$, in a process mediated by the activation of the NMDA receptors. These observations seem to be the basis for explaining glutamate-mediated inhibition of $\mathrm{O}_{2}$ consumption. Our results also suggest that glutamate mediated the changes in the mitochondrial membrane potential in cultured retinal cells, because a linear correlation between the loss of membrane potential and the reduction of mitochondrial respiration was observed. By using the fluorescent probe JC-1, glutamate was suggested to mediate significative changes in the mitochondrial membrane potential (Ankarcrona et al., 1995; Stout et al., 1998). Isaev et al. (1996) have also observed that glutamate collapsed the mitochondrial membrane potential, since the neuronal cells lost the ability to accumulate rhodamine 123 , a membrane potential-dependent probe.

Likely as observed for the alteration in membrane potential (Fig. 2, insert), changes in mitochondrial respiration occurred after addition of glutamate (Fig. 1, insert). Thus, the decrease in mitochondrial respiratory chain activity (Fig. 4) may help to explain the decrease in $\mathrm{O}_{2}$ consumption (Fig. 1) and the possible collapse of mitochondrial membrane potential (Figs. 2 and 3) upon a short exposure to glutamate. Our work seems to be supported by Ankarcrona et al. (1995), showing that glutamate induced the early deregulation of mitochondrial function, through the decrease in cellular energy charge and the collapse in mitochondrial membrane potential. According to this study, a proportion of retinal neurons could have died in the early acute phase of injury as a result of NMDA-receptor activation and partial inhibition of mitochondrial complexes activity (Fig. 4). Recently, inhibition of complex II/III and IV activities was observed in the surviving cortical neurons $24 \mathrm{~h}$ following glutamate exposure, although no changes in the activity of complex I were observed (Almeida et al., 1998). In that study, a decrease in mitochondrial complexes activity was suggested to be mediated by NMDA-receptor stimulation, leading to the increase in NOS activity and the formation of $\mathrm{ONOO}^{-}$, closely associated with the depletion of GSH (Almeida et al., 1998). Furthermore, thiol oxidation, a concomitant loss of mitochondrial complex I and a decreased activity of complex II and II/III after exposure of brain slices to an agonist of AMPA receptors, indicated that oxidative stress is a primary downstream effect after glutamate receptor activation, leading to mitochondrial dysfunction (Sriram et al., 1998). Interestingly, Sriram et al. (1998) also showed an inhibition of complex I after exposure of brain slices to $1 \mathrm{mM}$ glutamate. In addition, Atlante et al. (1996) have previously observed that glutamate $(100 \mu \mathrm{M})$ rapidly uncoupled oxidative phosphorylation in primary cultures of cerebellar granule neurons.

Exposure of cultured retinal cells to glutamate $(100 \mu \mathrm{M})$ increased the $\left[\mathrm{Ca}^{2+}\right]_{i}$ by about 5 -fold (Fig. 5) and the uptake of $\mathrm{Ca}^{2+}$ by about 6-fold after incubation for $2 \mathrm{~h}$ (Rego et al., 1998), indicating that the intracellular $\mathrm{Ca}^{2+}$ levels are largely increased even after a prolonged exposure to glutamate. Although the energy charge or the plasma membrane integrity of retinal cells was not significantly affected upon exposure to glutamate for $2 \mathrm{~h}$, a $20 \%$ reduction of cellular redox status was observed (Rego et al., 1998), as determined by the MTT (3-(4,5-dimethylthiazol-2-yl)2,5-diphenyltetrazolium bromide) assay, a proposed index used to evaluate mitochondrial function (Mosmann, 1983). In the retinal cells, exposure to glutamate or agonists of NMDA and AMPA/kainate receptors were shown to mediate cytotoxic effects, which were mediated by $\mathrm{Ca}^{2+}$ influx occurring principally through the receptor-associated channels (Ferreira et al., 1996). Furthermore, in chick telence- 
phali neurons, exposure to glutamate produced a concentration-dependent cytotoxicity after $30 \mathrm{~min}$, which was accompanied by lipid peroxidation, in a process partly mediated by the NMDA receptors (Jacobsson and Fowler, 1999).

The intracellular mechanism through which glutamate exerts the inhibition of mitochondrial respiratory chain activity after NMDA receptor activation in retinal cells may have involved the alteration of $\mathrm{Ca}^{2+}$ homeostasis. A transient increase in $\left[\mathrm{Ca}^{2+}\right]_{i}$ suggests a relevant role of intracellular $\mathrm{Ca}^{2+}$ sequestering mechanisms (Fig. 5). Under this perspective, mitochondria has been considered to be a target for glutamate neurotoxicity, because it plays an important role in buffering intracellular $\mathrm{Ca}^{2+}$ after glutamate exposure (Budd and Nicholls, 1996; Wang and Thayer, 1996). Moreover, a $\mathrm{Ca}^{2+}$-dependent disturbance of mitochondrial membrane potential, associated with ultrastructural alterations, was demonstrated to depend upon the activation of NMDA receptors (Isaev et al., 1996). Additionally, the entry of $\mathrm{Ca}^{2+}$ through the NMDA and the non-NMDA receptors has been shown to mediate the formation of ROS (Lafon-Cazal et al., 1993; Bindokas et al., 1996). Previously, van de Water et al. (1994) showed that intracellular hydroperoxides mediated the dissipation of the mitochondrial membrane potential, which could have occurred as a consequence of increased $\left[\mathrm{Ca}^{2+}\right]_{i}$, accompanied by an increase in mitochondrial $\mathrm{Ca}^{2+}$ concentration. Activation of NMDA glutamate receptors were shown to induce the formation of hydroperoxides and ROS generated by the mitochondria, as determined with the fluorescent probes hydroethidine (Bindokas et al., 1996; Castilho et al., 1999) or dihydrorhodamine 123 (Dugan et al., 1995). Formation of $\mathrm{O}_{2}^{-}$by the mitochondrial respiratory chain occurs at complex I and at the level of complex III or the ubisemiquinone, the ubiquinone radical (Turrens, 1997). Thus, the formation of $\mathrm{O}_{2}^{--}$was implicated as an obligate step in the intracellular events that culminate in cell death after NMDA and kainate receptor activation, as determined by the selective inactivation of aconitase activity, a marker of $\mathrm{O}_{2}^{--}$generation (Patel et al., 1996). Excessive formation of mitochondrial $\mathrm{O}_{2}^{--}$is metabolized by manganese superoxide dismutase (Mn-SOD), which can regulate membrane lipid peroxidation, $\mathrm{ONOO}^{-}$formation and mitochondrial dysfunction (Keller et al., 1998). Furthermore, an increased intracellular $\mathrm{Ca}^{2+}$ may stimulate mitochondrial nitric oxide synthase (NOS), associated with the inner mitochondrial membrane (Ghafourifar and Richter, 1997), which may have a major relevance in mitochondrial degeneration.

Taking this into account, the formation of ROS upon glutamate-mediated $\mathrm{Ca}^{2+}$ rise could be involved in the reduction of the activity of mitochondrial com- plexes in retinal cells in culture (Fig. 4), causing the inhibition of oxidative phosphorylation (Fig. 1). Accordingly, exposure of isolated mitochondria to the hydroxyl radical (HO) impaired the activity of complex I (Dykens, 1994), and scavenger antioxidants, such as vitamin $\mathrm{E}$, were shown to reduce excitotoxic cell death in cerebellar granule cultures (Ciani et al., 1996).

In conclusion, our data provide a link between NMDA receptor activation and a reduced activity of mitochondrial respiratory chain complexes upon exposure of chick retinal cells to glutamate. A reduction in oxidative phosphorylation due to glutamate exposure may be particularly relevant after ischemia situations, where massive activation of glutamate receptors have long been considered a key factor for determining the fate of retinal neurons.

\section{Acknowledgements}

This work was supported by JNICT (Portuguese Research Council) and the Human Capital Mobility Program (EU) Proposal ERB 4050 PL 932039. We thank Professor Carlos Palmeira (Department of Zoology, University of Coimbra) for critically reading the previous version of this manuscript and Professor Carlos B. Duarte (Department of Zoology, University of Coimbra) for making MK-801 available.

\section{References}

Almeida A, Heales, S.J.R., Bolanos, J.P., Medina, J.M., 1998. Glutamate neurotoxicity is associated with nitric oxide-mediated mitochondrial dysfunction and glutathione depletion. Brain Res. 790, 209-216.

Ankarcrona, M., Dypbukt, J.M., Bonfoco, E., Zhivotovsky, B., Orrenius, S., Lipton, S.A., Nicotera, P., 1995. Glutamate-induced neuronal death: a sucession of necrosis or apoptosis depending on mitochondrial function. Neuron 15, 961-973.

Atlante, A., Gagliardi, S., Minervini, G.M., Marra, E., Passarella, S., Calissano, P., 1996. Rapid uncoupling of oxidative phosphorylation accompanies glutamate toxicity in rat cerebellar granule cells. NeuroReport 7, 2519-2523.

Bindokas, V.P., Jordan, J., Lee, C.C., Miller, R.J., 1996. Superoxide production in rat hippocampal neurons: selective imaging with hydroethidine. J. Neurosci. 16, 1324-1336.

Brautigan, D.L., Ferguson-Miller, S., Margoliash, E., 1978. Mitochondrial cytochrome c: preparation and activity of native and chemically modified cytochrome c. Meth. Enzymol. 53, 128164.

Budd, S.L., Nicholls, D.G., 1996. Mitochondria, calcium regulation, and acute glutamate excitotoxicity in cultured cerebellar granule cells. J. Neurochem. 67, 2282-2291.

Castilho, R.F., Ward, M.W., Nicholls, D.G., 1999. Oxidative stress, mitochondrial function, and acute glutamate excitotoxicity in cultured cerebellar granule cells. J. Neurochem. 72, 1394-1401.

Ciani, E., Grøneng, L., Voltattorni, M., Rolseth, V., Contestabile, A., Paulsen, R.E., 1996. Inhibition of free radical production or 
free radical scavenging protects from the excitotoxic cell death mediated by glutamate in cultures of cerebellar granule neurons. Brain Res. 728, 1-6.

Dugan, L.L., Sensi, S.L., Canzoniero, L.M.T., Handran, S.D., Rothman, S.M., Lin, T.-S., Goldberg, M.P., Choi, D.W., 1995. Mitochondrial production of reactive oxygen species in cortical neurons following exposure to $N$-methyl-D-aspartate. J. Neurosci. $15,6377-6388$.

Dykens, J.A., 1994. Isolated cerebral and cerebellar mitochondria produce free radicals when exposed to elevated $\mathrm{Ca} 2+$ and $\mathrm{Na}+$ : implications for neurodegeneration. J. Neurochem. 63, 584-591.

Ferreira, I.L., Duarte, C.B., Carvalho, A.P., 1996. $\mathrm{Ca}^{2+}$ influx through glutamate receptor-associated channels in retina cells correlates with neuronal cell death. Eur. J. Pharmacol. 302, 153-162.

Ghafourifar, P., Richter, C., 1997. Nitric oxide synthase activity in mitochondria. FEBS Lett. 418, 291-296.

Gunasekar, P.G., Kanthasamy, A.G., Borowitz, J.L., Isom, G.E., 1995. NMDA receptor activation produces concurrent generation of nitric oxide and reactive oxygen species: implication for cell death. J. Neurochem. 65, 2016-2021.

Huba, R., Hofmann, H.D., 1990. Identification of GABAergic amacrine cell-like neurons developing in retina monolayer cultures. Neurosci. Lett. 117, 37-42.

Isaev, N.K., Zorov, D.B., Stelmashook, E.V., Uzbekov, R.E., Kozhemyakin, M.B., Victorov, I.V., 1996. Neurotoxic glutamate treatment of cultured cerebellar granule cells induces $\mathrm{Ca} 2 \pm$ dependent collapse of mitochondrial membrane potential and ultrastructural alterations of mitochondria. FEBS Lett. 392, $143-147$.

Jacobsson, S.O.P., Fowler, C.J., 1999. Dopamine and glutamate neurotoxicity in cultured chick telencephali cells: effects of NMDA antagonists, antioxidants and MAO inhibitors. Neurochem. Int. $34,49-62$.

Kamo, N., Muratsugu, M., Hongoh, R., Kobatake, Y., 1979. Membrane potential of mitochondria measured with an electrode sensitive to tetraphenyl phosphonium and relationship between proton electrochemical potential and phosphorylation potential in steady-state. J. Membr. Biol. 49, 105-121.

Keller, J.N., Kindy, M.S., Holtsberg, F.W., Clair St, D.K., Yen, H.C., Germeyer, A., Steiner, S.M., Bruce-Keller, A.J., Hutchins, J.B., Mattson, M.P., 1998. Mitochondrial manganese superoxide dismutase prevents neural apoptosis and reduces ischemic brain injury: suppression of peroxynitrite production, lipid peroxidation, and mitochondrial dysfunction. J. Neurosci. 18, 687-697.
King, T.E., 1967. Preparations of succinate-cytochrome c reductase and the cytochrome b-cl particle and reconstitution of succinatecytochrome c reductase. Meth. Enzymol. 10, 216-225.

Lafon-Cazal, M., Pietri, S., Culcasi, M., Bockaert, J., 1993. NMDAdependent superoxide production and neurotoxicity. Nature 364, 535-537.

Mosmann, T., 1983. Rapid colorimetric assay for cellular growth and survival: application to proliferation and cytotoxicity assays. J. Immunol. Meth. 65, 55-63.

Patel, M., Day, B.J., Crapo, J.D., Fridovich, I., McNamara, J.O., 1996. Requirement for superoxide in excitotoxic cell death. Neuron 16, 345-355.

Ragan, C.I., Wilson, M.T., Darley-Usmar, V.M., Lowe, P.N., 1987. Subfractionation of mitochondria and isolation of the proteins of oxidative phosphorylation. In: Mitochondria, a Practical Approach. IRL Press, London, pp. 79-112.

Rego, A.C., Santos, M.S., Oliveira, C.R., 1996. Oxidative stress, hypoxia and ischemia-like conditions increase the release of endogenous amino acids by distinct mechanisms in cultured retinal cells. J. Neurochem. 66, 2506-2516.

Rego, A.C., Areias, F.M., Santos, M.S., Oliveira, C.R., 1998. Effect of glucose deprivation and acute glutamate exposure in cultured retinal cells. Exp. Neurology 153, 128-134.

Sriram, K., Shankar, S.K., Boyd, M.R., Ravindranath, V., 1998. Thiol oxidation and loss of mitochondrial complex I precede excitatory amino acid-mediated neurodegeneration. J. Neurosci. 18, 10,287-10,296.

Stout, A.K., Raphael, H.M., Kanterewicz, B.I., Klann, E., Reynolds, I.J., 1998. Glutamate-induced neuron death requires mitochondrial calcium uptake. Nature Neuroscience 1, 366-373.

Tapia, R., Medina-Ceja, L., Peña, F., 1999. On the relationship between extracellular glutamate, hyperexcitation and neurodegeneration, in vivo. Neurochem. Int. 34, 23-31.

Turrens, J.F., 1997. Superoxide production by the mitochondrial respiratory chain. Biosci. Reports 17, 3-8.

van de Water, B., Zoeteweij, J.P., de Bont, H.J.G.M., Mulder, G.J., Nagelkerke, J.F., 1994. Role of mitochondrial Ca2 + in the oxidative stress-induced dissipation of the mitochondrial membrane potential. J. Biol. Chem. 269, 14,546-14,552.

Vizi, E.S., Mike, A., Tarnawa, I., 1997. The functional study of kainate receptors - hopes and doubts. Trends in Neurosci. 20, 396.

Wang, G.J., Thayer, S.A., 1996. Sequestration of glutamate-induced $\mathrm{Ca} 2+$ loads by mitochondria in cultured rat hippocampal neurons. J. Neurophysiol. 76, 1611-1621. 